\title{
Anatomical and physiological characteristics of two argentine wheat cultivars
}

\author{
Características anatômicas e fisiológicas de dois cultivares \\ argentinos de trigo
}

\author{
Raúl Roberto Filgueira ${ }^{1}$ Inés Silvina Golik ${ }^{2}$ \\ Oliverio Guillermo Sarli ${ }^{3}$ Raúl Jaime Jatimliansky ${ }^{4}$
}

\section{RESUMO}

Dois cultivares argentinos de trigo (Triticum aestivium L), Buck Cencerro (BC), com germoplasma tradicional e Buck Pucará (BP), com germoplasma mexicano, foram pesquisados para comparar as características anatomicas e fisiológicas da folha bandeira medida no espigamento (estádio E59), na antese (estádio E69) e na fase de grão aquoso completo (estádio E71). Nos dois cultivares, a taxa fotossintética foi semelhante no mesmo estágio fenológico, exceto no E71. As médias no estádio E59 foram superiores às dos estágios E69 e E71 nos dois cultivares $(22,70 ; 18,40$ e 10,40 $\mu \mathrm{mol} \mathrm{m}$

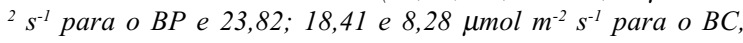
respectivamente). Nos três estádios, as taxas de transpiração

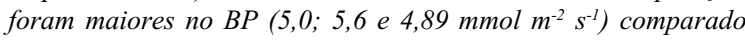
ao $B C\left(3,3 ; 4,4\right.$ e 2,57 mmol $\left.\mathrm{m}^{-2} \mathrm{~s}^{-1}\right)$. Consequentemente, a eficiência de uso instantâneo de água foi maior no BC, quando comparado com o BP. Não foram observadas diferenças de área foliar específica para cultivares e estádios fenológicos (área do mesófilo por unidade de massa), determinada por adsorção física de nitrogênio a baixa temperatura $\left(78^{\circ} \mathrm{K}\right)$, registrando-se média geral de $8,9 \mathrm{~m}^{2} \mathrm{~g}^{-1}$. Esse valor foi semelhante a outros reportados em trabalhos prévios com $\boldsymbol{T}$. aestivum L. e maiores que os determinados para Ligustrum lucidum Aiton, pela mesma técnica. As diferenças podem ser atribuidas à rugosidade da parede celular e as próprias dimensões da célula. Não houve correlação positiva entre área especifica e taxa fotossintética para cultivares ou estádios fenológicos.

\begin{abstract}
Palavras-chave: área específica da folha, área do mesófilo, troca do dióxido de carbono, transpiração, anatomia da folha, condutância.
\end{abstract}

\section{ABSTRACT}

Two Argentine field grown wheat cultivars (Triticum aestivum L.), Buck Cencerro (BC) with traditional germoplasm, and Buck Pucará (BP) with Mexican germoplasm, have been investigated in order to compare anatomical and physiological characteristics of the flag leaf measured in heading (stage E59), anthesis (stage E69) and kernel water ripe (stage 71). In both cultivars, photosynthetic rate was not different for the same phenological stage, except for E71. Averages in stage E59 were higher than stages E69 and E71 for both cultivars (22.70, 18.40 and $10.40 \mu \mathrm{mol} \mathrm{m} \mathrm{m}^{-2} \mathrm{~s}^{-1}$ for BP and 23.82, 18.41 and $8.28 \mu \mathrm{mol}$ $m^{-2} s^{-1}$ for $B C$, respectively). Transpiration rates were higher in $B P\left(5.0,5.6\right.$ and $\left.4.89 \mathrm{mmol} \mathrm{m} \mathrm{m}^{-2} \mathrm{~s}^{-1}\right)$ than $B C$ (3.3, 4.4 and 2.57 mmol $\mathrm{m}^{-2} \mathrm{~s}^{-1}$ ) for stages E59, E69 and E71, respectively. Consequently, instantaneous water use efficiencies were higher in BC than in BP. No difference between cultivars and phenological stages was observed in specific surface area (mesophyll area per unit mass) determined by physical adsorption of nitrogen at low temperature $\left(78^{\circ} \mathrm{K}\right)$; the mean was $8.9 \mathrm{~m}^{2} \mathrm{~g}$ ${ }^{1}$. It was similar as values found in previous works, in others $\boldsymbol{T}$. aestivum $L$. and greater than the values found for Ligustrum lucidum Aiton, by the same technique. Differences could be attributed to the roughness of the cell wall and the dimensions of the cell itself. No positive correlation between specific surface

${ }^{1}$ Físico, Facultad de Ciencias Agrarias y Forestales, Universidad Nacional de La Plata, Profesor, Doctor en Física, Area de Física Biológica, CC. 31, 1900, La Plata, Argentina, Miembro del Consejo Nacional de Investigaciones Científicas y Técnicas (CONICET, Argentina).

${ }^{2}$ Ingeniera Agrónoma, Facultad de Ciencias Agrarias y Forestales, Universidad Nacional de La Plata, Asistente, Area de cerealicultura, CC. 31, 1900, La Plata, Argentina. E-mail: cereali@ceres.agro.unlp.edu.ar. Corresponding author.

${ }^{3}$ Físico, Facultad de Ciencias Agrarias y Forestales, Universidad Nacional de La Plata, Profesor Asistente, Area de Física Biológica, CC. 31, 1900, La Plata, Argentina.

${ }^{4}$ Bioquímico, Facultad de Ciencias Agrarias y Forestales, Universidad Nacional de La Plata, Profesor, Doctor en Farmacia y Bioquímica, Area de Física Biológica, CC. 31, 1900, La Plata, Argentina, Miembro del Consejo Nacional de Investigaciones Científicas y Técnicas (CONICET,Argentina). 
and photosynthetic rate was observed neither for cultivars nor for phenological stages.

Key words: specific leaf area, mesophyll area, carbon dioxide exchange, transpiration, leaf anatomy, conductance.

\section{INTRODUCTION}

Although considerable amount of information concerning leaf photosynthetic rate and transpiration, stomatal frequency and other morphological and physiological properties of wheat has been reported (EVANS et al., 1975; NELSON, 1988; AUSTIN, 1989), there is little information regarding to the internal surface of leaves (TURRELL, 1936; ElSHARKAWY \& HESKETH, 1965; NOBEL, 1980 e 1991). The importance of the internal exposed surface of the leaves for plant activity is well recognized, specially in certain phenological stages of development of the crop, i.e. the critical period (from 20 days before flowering to10 days after flowering) and the grain filling period. These phases are of great importance for the generation of number of grains and its final weight, respectively. Water, oxygen and carbon dioxide are exchanged through this surface and the rates of most cellular activities depend on this exchange. However, few attempts have been made to measure the internally exposed leaf area. TURRELL(1936), El-SHARKAWY \& HESKETH(1965), and NOBEL $(1980,1991)$ suggested geometrical approximations for the determination of this internal moist surface. In a recent paper KEBEDE et al. (1992) reported physiological and anatomical features, including estimations of internal surface area, of $\boldsymbol{T}$. dicoccoides and $\boldsymbol{T}$. aestivum wheat accessions differing in photosynthetic rate. An alternative technique for measuring the area of the internal exposed surface of leaves has been proposed by CASCARINI DE TORRE et al. $(1978,1981,1984)$. The method is based on the physical adsorption process of gases and the obtained isotherm is interpreted with the BET model(BRUNAUER et al., 1938). On the other hand, OCAMPO SANCHEZ (1980) studied the adsorption of carbon dioxide and nitrogen on amorphous and hexagonal ice. The isotherms and specific values obtained by OCAMPO SANCHEZ (1980), were in close agreement with the values obtained in other works on frozen Ligustrum lucidum Aiton leaves (CASCARINI DE TORRE et al., 1978) and on T. Aestivum flag leaves (GOLIK et al., 1995; FILGUEIRA et al., 1998 and FILGUEIRA et al., 2000).

In the present study two Argentine Triticum

aestivum L. cultivars were investigated in order to measure and compare the physiological traits photosynthetic rate and transpiration, as well as the anatomical features stomatal frequency, external and specific leaf surface area in the flag leaf, at differents phenological stages and possible correlation among some of them.

\section{MATERIALS AND METHODS}

The Argentine commercial bread wheat cultivars Buck Cencerro (BC) and Buck Pucará (BP) were used in the experiments. $\mathrm{BC}$ has traditional germoplasm, middle-yielding potential, middle-croping index and high protein content in the grain. BP is a modern wheat, it has Mexican germoplasm, high-yielding potential, highcroping index and lower protein content in the grain than BC. The plants studied were grown in the field on a Typical Argiudol soil at the La Plata Faculty of Agronomy and Forestry Farm. They were sown in the last week of July in parcels of $5.5 \mathrm{mx} 1.4 \mathrm{~m}\left(7.7 \mathrm{~m}^{2}\right)$, with a density of 300 plants $\mathrm{m}^{-2}$, in a randomized complete block design with four replications. Plots were not irrigated because no water shortage occurred during the study. Precipitation was $36 \%$ above the 30 -year average (958mm).

All structural and functional measurements were carried out on the flag leaf of the main shoot at three developmental stages: E59 (heading), E69 (anthesis) and E71 (kernel water ripe) as described by TOTTMAN et al (1979). Stomatal frequency, internal and external leaf area were determined only in stage E69.

An infrared gas analyzer (LI-6200 LI-COR, LINCOLN, NE, USA) was used to measure the partial pressure of $\mathrm{CO}_{2}$ in the cuvette and in the atmosphere. Photosynthetic active radiation (PAR) incident on the leaf during the measurements, E59, E69 and E71 stages of development, was always over $1800 \mu \mathrm{mol} \mathrm{m} \mathrm{m}^{-2} \mathrm{~s}^{-1}$. Carbon dioxide concentration in the atmosphere was approximately $350 \mu \mathrm{L} \mathrm{L}^{-1}$. Temperatures in the cuvette ranged from 20 to $25^{\circ} \mathrm{C}$. A steady state porometer (LI1600 LI-COR, LINCOLN, NE, USA) was used to measure the evapotranspiration by the flag leaves. Three replications per plot at each stage were made for both gas exchange measurements. Instantaneous water use efficiency (WUE) was estimated by the relation between carbon dioxide assimilation and transpiration, both expressed per leaf area. Stomatal frequency was obtained as reported by KEBEDE et al. (1992). Stomata were counted on ten developed mature flag leaves taken at random. Replicates of the upper and the lower surface were made by applying clear fingernail polish to the midportions of the leaves. Stomatal number per square millimeter were determined using a microscope equipped with a calibrated eyepiece micrometer.

Ciência Rural, v. 33, n. 4, jul-ago, 2003. 
Leaf copies were made with heliographic paper and later used to obtain, with a planimeter, the external mean leaf surface. Data were determined from 31 flag leaves, of each cultivar, taken at random from the plots.

The specific surface (surface area/mass unit) was measured using the technique reported by CASCARINI DE TORRE et al. (1984). The sample, consisting of 300 leaf discs each $8 \mathrm{~mm}$ in diameter (from about 30 flag leaves taken at random), was introduced in a glass bulb and connected with a vacuum line (pressure around $2 \mathrm{~Pa}$ ) for $5 \mathrm{~min}$ at room temperature (clean vacuum). After this clean vacuum treatment, the sample bulb was frozen with dry ice and additionally evacuated for several hours until no further evolution of gas occurred. After closing the stopcock of the sample bulb, the dry-ice bath was replaced by a thermostat bath consisting of a Dewar flask filled with liquid nitrogen. The next step was to measure the dead volume with helium and the last step was to admit the adsorbate, gaseous nitrogen, to obtain the adsorption isotherm. Careful microscopic observations of the samples both before and after the treatment were made in order to determine shrinkage or rupture of the cells. Moreover, samples were weighed before and after treatments, in order to test the loss of water which was always lower than $3 \%$

Statistical analysis of parameters was made by analysis of variance (ANOVA). Varieties and dates were considered fixed effects, whereas replications were random effects (COCHRAN \& COX, 1965). Means were separated using LSD test of error 5\% when ANOVA showed a significant treatment effect (LISON, 1969).

\section{RESULTS AND DISCUSSION}

Results of carbon dioxide assimilation per leaf area (A), transpiration per leaf area (T), water vapor conductances $\left(\mathrm{g}_{\mathrm{s}}\right)$, and specific surface area, are shown in Table I. In both cultivars, $\mathrm{CO}_{2}$ assimilation rate was not different for the same phenological stage, except for E71. On the other hand, $\mathrm{CO}_{2}$ assimilation rate were higher for stage E59 than for stages E69 and E71. As NELSON (1988) has shown, the photosynthetic rate is decreasing as grain filling occurs. Data obtained for A in our study were similar to those reported for other wheat cultivars (KEBEDE et al., 1992; MARTIN et al., 1994). In all stages studied the transpiration rates were higher in BP than in BC (Table 1). Similar trends were observed for conductances to water vapor, i.e. BP data were higher than $\mathrm{BC}$ means (Table 1). Consequently, the water use efficiency (WUE $=\mathrm{A} /$
T) was higher in $\mathrm{BC}\left(\mathrm{E} 59: 7.2 \pm 1.7 \mathrm{mmol} \mathrm{mol}^{-1}\right.$; E69: $4.2 \pm 0.9$ mmol mol ${ }^{-1}$;E71: $\left.3.22 \pm 0.7 \mathrm{mmol} \mathrm{mol}^{-1}\right)$ than in BP (E59: $4.5 \pm 0.8 \mathrm{mmol} \mathrm{mol}^{-1} ; \mathrm{E} 69: 3.3 \pm 0.6 \mathrm{mmol} \mathrm{mol}^{-1} ; \mathrm{E} 71: 2.1 \pm 0.7$ mmol mol$\left.{ }^{-1}\right)$. The classical model based on gas diffusion can explain the observations. This model considers a stomatal conductance common to water vapor and carbon dioxide and a mesophyll conductance specific to carbon dioxide. A decrease in stomatal conductance acts directly on transpiration and partially on photosynthesis, increasing the ratio A/T (VON CAEMMERER \& FARQUHAR, 1981; NOBEL, 1991). Increasing efficiency of water use could result from the restriction on the ability of the plants to extract water from the soil. Reduced tillering will be benefical to restrict water transfer from the soil (EVANS et al., 1975) and may be related to the differences obtained in WUE as BC produced fewer number of tillers than $\mathrm{BP}$. The yield on a tiller basis was higher in $\mathrm{BC}\left(0.94 \mathrm{~g}_{\text {tiller }}{ }^{-1}\right)$ than in $\mathrm{BP}$ $\left(0.69 \mathrm{~g} \mathrm{tiller}^{-1}\right)$ while BP produced more tillers per square meter (421) than BC (257) and, consequently, a higher yield per hectar than BC. Stomatal frequency was higher on the upper leaf surface than the lower leaf surface in both cultivars. Higher stomatal frequency was obtained in BC than BP for the upper leaf surface only (Table 2). RAMA Das \& RAJENDRUDU (1977) reported a high correlation of the faster rates of carbon dioxide fixation with the higher stomatal density in leaves of some crop plants. In the present study no positive correlation between stomatal density, external leaf area and carbon dioxide assimilation was found.

With regard to specific surface area, no difference was found between varieties and phenological stages (Table 1). The mean $8.9 \mathrm{~m}^{2} \mathrm{~g}^{-1}$ was similar to values found in others T. aestivum L. (2.24 to $\left.8.92 \mathrm{~m}^{2} \mathrm{~g}^{-1}\right)$ for

Table 1 - Carbon dioxide assimilation rate (A), transpiration (T), conductance for water vapor $\left(g_{s}\right)$ and specific leaf surface area, measured in heading (stage E59), anthesis (stage E69) and kernel water ripe (stage E71) in the flag leaf of two wheat cultivars (Triticum aestivum L.).

\begin{tabular}{cccccc}
\hline & & $\mathrm{A}$ & $\mathrm{T}$ & $\mathrm{Gs}$ & \\
$\mathrm{CV}$ & Stage & $\begin{array}{c}\mu \mathrm{mol} \mathrm{m}_{1}^{-2} \mathrm{~s}^{-} \\
\mathrm{mmol} \mathrm{m}^{-2} \mathrm{~s}^{-1}\end{array}$ & $\begin{array}{c}\text { Specific surface } \\
\text { area m }^{2} \mathrm{~g}^{-1} \mathrm{~s}^{-1}\end{array}$ & \\
\hline BP & E59 & $22.70 \mathrm{a}^{(1)}$ & $5.00 \mathrm{~b}$ & $0.422 \mathrm{a}$ & $7.67 \mathrm{a}$ \\
& E69 & $18.40 \mathrm{~b}$ & $5.60 \mathrm{a}$ & $0.443 \mathrm{a}$ & $10.37 \mathrm{a}$ \\
& E71 & $10.40 \mathrm{c}$ & $4.89 \mathrm{~b}$ & $0.403 \mathrm{a}$ & $8.71 \mathrm{a}$ \\
BC & E59 & $23.82 \mathrm{a}$ & $3.30 \mathrm{c}$ & $0.278 \mathrm{c}$ & $7.50 \mathrm{a}$ \\
& E69 & $18.41 \mathrm{~b}$ & $4.40 \mathrm{~b}$ & $0.341 \mathrm{~b}$ & $9.95 \mathrm{a}$ \\
& E71 & $8.28 \mathrm{~d}$ & $2.57 \mathrm{~d}$ & $0.192 \mathrm{~d}$ & $9.12 \mathrm{a}$ \\
\hline
\end{tabular}

(1) Means within a parameter followed by the same letter are not significantly different as determined by LSD test at 0.05 probability level of error.

Ciência Rural, v. 33, n. 4, jul-ago, 2003. 
Table 2 - Density of stomata, external, measured in anthesis (stage E69) in the flag leaf of two wheat cultivars (Triticum aestivum $\mathrm{L}$.).

\begin{tabular}{|c|c|c|c|}
\hline \multirow{3}{*}{$\mathrm{CV}$} & \multicolumn{2}{|c|}{ Stomal density } & External leaf area \\
\hline & \multicolumn{2}{|c|}{ Number $\mathrm{mm}^{-2}$} & $\mathrm{~mm}^{2}$ \\
\hline & Upper face & lower face & \\
\hline $\mathrm{BP}$ & $44 b^{(1)}$ & $34 \mathrm{c}$ & $1722 b$ \\
\hline $\mathrm{BC}$ & $49 \mathrm{a}$ & $32 \mathrm{c}$ & $2354 \mathrm{a}$ \\
\hline
\end{tabular}

(1) Means within a parameter followed by the same letter are not significantly different as determined by LSD test at 0.05 probability level of error.

GOLIK etal. (1995); FILGUEIRA etal.(1998); FILGUEIRA et al. (2000) and was greater than the values found for Ligustrum lucidum Aiton $\left(1.2 \mathrm{~m}^{2} \mathrm{~g}^{-1}\right)$ for CASCARINI DE TORRE et al. (1984). This result could be explained considering the mesophyll structure of both species (FILGUEIRA et al., 2000). If we do the calculation of specific surface area thinking of a leaf as collection of water spheres, with radius $20 \mu \mathrm{m}$, and with a smooth surface, we obtain $0.5 \mathrm{~m}^{2} \mathrm{~g}^{-1}$. OCAMPO SANCHEZ (1980) working with physical adsorption of nitrogen on amorphous ice surfaces calculated specific surfaces around $3 \mathrm{~m}^{2} \mathrm{~g}^{-1}$, in a close agreement with our results. As mentioned above, our larger values could be assigned to the architecture of the mesophyll leaf, but also to the roughness of the cell wall. In fact, the cell wall surface is not smooth, but a complex wrinkled surface of microfibrils and water (ALBERTS et al., 1992) and the method of CASCARINI DE TORRE et al. (1984) would be able to detect the furrowness of this internal exposed surface.

No correlation between the photosynthetic rate and the specific surface was found, neither different phenological stages nor both cultivars. This result agrees with that reported by JELLING \& LEECH (1984); KEBEDE etal. (1992) and FILGUEIRA et al. (1998, 2000). The surface of mesophyll that is in contact with the atmosphere could not be directly related to the photosynthetic activity, but with other causes, probably biochemical, like the concentration of sucrosa and the Rubisco activity.

\section{CONCLUSIONS}

$\mathrm{BC}$ were more efficient in the use of the water that BP. In the present study, no positive correlation between stomatal density, external leaf area and carbon dioxide assimilation was found. Besides, no correlation between the internal surface and the photosyntetic rate was found neither for different cultivars nor phenological stages.

\section{ACKNOWLEDGEMENTS}

We would like to thank the Consejo Nacional de Investigaciones Científicas y Técnicas (CONICET) for economical support.

\section{REFERENCES}

ALBERTS, B., et al. Biología molecular de la célula. 2.ed. Barcelona : Omega, 1992. 1300p.

AUSTIN, R.B. Genetic variation in photosynthesis. Journal of Agricultural Science, New York, v.23, p.541-546, 1989.

BRUNAUER, S.; EMMETT, P.H.; TELLER, E. Adsorption of gases in multimolecular layers. Journal of American Chemical Society, Washington, v.60, p.309-319, 1938.

CASCARINI DE TORRE, L.E.; SÍVORI, E.M.; FILGUEIRA, R.R. Use of the BET method to measure area of internal exposed surface of leaves. Photosynthetica, Prague, v.18, p.365-369, 1984.

COCHRAN, W.G.; COX, G. M. Experimental designs. 2.ed. New York : Wiley, 1965. 611p.

EL-SHARKAWY, M.; HESKETH, J. Photosynthesis among species in relation to characteristics of leaves anatomy and $\mathrm{CO}_{2}$ diffusion resistences. Crop Science, Madison, v.5, p.517-521, 1965 .

EVANS, L.T.; WARDLAW, I.F; FISCHER, R.A. Wheat. In: EVANS, L.T. Crop physiology, some case histories. Cambridge : Cambridge University, 1975. p.101-147.

FILGUEIRA, R.R. et al. La superficie específica foliar en genotipos del género Triticum y su relación con el intercambio gaseoso. Revista de la Facultad de Agronomía, La Plata, v.103, n.2, p.177-184, 1998.

FILGUEIRA, R.R. et al. Mesophyll surface area as measure by physical adsorption of nitrogen: the case of wheat. Cereal Research Communications, Szeged, v.28, n.1-2, p.139-145, 2000 .

GOLIK, S.I. et al. La superficie interna foliar en diez cultivares de trigo pan (Triticum aestivum L) y su relación con la tasa fotosintética. Revista de la Facultad de Agronomía, La Plata, v.71, n.2, p.269-273, 1995.

JELLINGS, A.J.; LEECH, R.M. Anatomical variation in the first leaf of nine Triticum genotypes and its relationship to photosynthesis in wheat. New Phytologist, Perth, v.96, p.371382, 1984.

KEBEDE, H. et al. Physiological and anatomical features of two Triticum dicoccoides wheat accessions differing in photosynthetic rate. Crop Science, Madison, v.32, p.138143, 1992.

LISON, L. Statistique appliqué à la biologie expérimental. Paris : Gauthier-Villars, 1968. 357p.

MARTIN, B.; KEBEDE, H.; RILLING, C. R. Photosynthetic differences among Lycopersicon species and Triticum aestivum cultivars. Crop Science, Madison, v.34, p. 113-118, 1994.

Ciência Rural, v. 33, n. 4, jul-ago, 2003. 
NELSON, C.J. Genetic associations between photosynthetic characteristics and yield: review of the evidence. Plant Physiology and Biochemistry, Paris, v.26, p.543-554, 1988.

NOBEL, P.S. Leaf anatomy and water use efficiency. In: TURNER, E.C.; KRAMER, P.J. Adaptation of plants to water and high temperature stress. New York : Wiley, 1980. Cap.4, p.43-55.

NOBEL, P.S. Physicochemical and environmental plant physiology. San Diego : Academic, 1991. 635p.
TOTTMAN D.R.; MAKEPEACE, R.J.; BROAD, H. An explanation of the decimal code for the growth stages of cereals, with illustrations. Annals of Applied Biology, Warwick, v.93, p.221-234, 1979.

TURRELL, F.M. The area of the internal exposed surface of dicotyledon leaves. American Journal of Botany, Columbus, v.23, p.255-263, 1936.

VON CAEMMERER, S.; FARQUHAR, G.D. Some relationships between the biochemistry of photosynthesis and the gas exchange of leaves. Planta, New York, v.153, p.376-387, 1981. 